\title{
GEL NANOEMULSION OF RAMBUTAN (NEPHELIUM LAPPACEUM L.) FRUIT PEEL EXTRACTS: FORMULATION, PHYSICAL PROPERTIES, SUNSCREEN PROTECTING, AND ANTIOXIDANT ACTIVITY
}

\author{
MUHTADI*, ANDI SUHENDI, ERINDYAH RETNO WIKANTYASNING
}

Department of Pharmacy, Faculty of Pharmacy, Universitas Muhammadiyah Surakarta, Jl. A. Yani Tromol Pos I, Pabelan Kartasura Surakarta 57102, Central of Java, Indonesia. Email: muhtadi@ums.ac.id

Received: 09 May 2017, Revised and Accepted: 26 July 2017

ABSTRACT

Objective: The aim of this study is to determine the optimum formulation of gel nanoemulsion of the rambutan fruit peel extracts (RFPEs), sunscreen protecting factor, and antioxidant activity using 1,1-diphenyl-2-picrylhydrazyl (DPPH) and ferric thiocyanate (FTC) methods.

Materials and Methods: Formulation was optimized based on the variety of concentrations of RFPE, namely, 0.25\%; $0.38 \%$; $0.51 \%$; and $0.63 \%$. Gel nanoemulsion was characterized based on a number of the physical and chemical properties, such as pH, viscosity, adhesion, spread property, stability, and particle size. Sunscreen protecting factor and antioxidant activity were conducted using spectrophotometer ultraviolet-visible.

Results: The result showed that the particle size of gel nanoemulsion formulation 1 (FI), FII, FIII, and FIV were at $13.30 \pm 4.00 \mathrm{~nm}, 1.90 \pm 9.70 \mathrm{~nm}$, $2.70 \pm 13.60 \mathrm{~nm}$, and $14.50 \pm 2.50 \mathrm{~nm}$, respectively. Based on transmission electron microscopy image, it showed that formula with the concentration of $0.25 \%$ of RFPE could form nanoemulsion particle aggregate with good dispersion. The varied concentrations of RFPE statistically indicated no significant differences among adhesive, spread property, and viscosity of all formulas. Formula 1 showed the highest sunscreen protecting factor with the value of sun-protecting factor at $6.450 \pm 0.002$, followed by F4, F3, and F2 with the values in sequence at $9.370 \pm 0.002,10.120 \pm 0.001$, and $13.120 \pm 0.001$, respectively. The antiradical activity of the gel nanoemulsion RFPE with inhibitory concentration $50 \%\left(\mathrm{IC}_{50}\right)$ value was at $9.32 \pm 0.05 \mu \mathrm{g} /$ $\mathrm{mL}$. Meanwhile, the higher value of branded product and Vitamin E, which $\mathrm{IC}_{50}$ were $40.41 \pm 0.97$ and $10.41 \pm 0.05 \mu \mathrm{g} / \mathrm{mL}$, respectively. In contrast, gel nanoemulsion of RFPE had the lowest inhibition on FTC method. The highest inhibition potency was showed by Vitamin E $(79.07 \pm 7.62 \%)$, followed by branded product $(60.07 \pm 13.23 \%)$ as comparison.

Conclusions: The gel nanoemulsion of RFPEs of FIII had a good physical stability and sunscreen protection activity. The antioxidant activity of gel nanoemulsion of RFPE by DPPH and FTC methods were $\mathrm{IC}_{50}$ value of $9.32 \pm 0.05 \mu \mathrm{g} / \mathrm{mL}$ and $\%$ inhibition of $51.09 \pm 0.99 \%$.

Keywords: Nephelium lappaceum, Gel nanoemulsion, Sunscreen protecting, Antioxidant activity.

(c) 2017 The Authors. Published by Innovare Academic Sciences Pvt Ltd. This is an open access article under the CC BY license (http://creativecommons. org/licenses/by/4. 0/) DOI: http://dx.doi.org/10.22159/ajpcr.2017.v10i11.19787

\section{INTRODUCTION}

Rambutan is a tropical edible fruit commonly easy to be found in Indonesia. Commonly, flash of rambutan is consumed, and the fruit peel becomes waste. On the other side, some researches have revealed that the fruit peel has certain chemical compounds that are potential to be the medical remedies. Pharmacology showed that rambutan extract has some antidiabetic and anticholesterolemia activities in rat models [1]. Our previous research showed that rambutan fruit peel extracts had good potency as the antioxidant higher than Vitamin E as standard [2]. As a consequence, the rambutan fruit peel could be the natural antioxidant resources. Antioxidant activity could not be separated from any chemical active compounds, such as ellagic acid, corilagin, and geraniin [3]. Our previous study on the isolation of active compound found the ethyl gallic as an active compound [2].

The application of antioxidant agent is wide because most of the diseases are initialized by oxidation by radical compounds. One of the applications in human life is cosmetics, which is functionalized as the antioxidant and sunscreen protector. It is important to use antioxidant or sunscreen protector because of sum radicals in environment and ultraviolet (UV) light radiation. The side effect of UV radiation, especially UVB leads to sunburn, skin pigmentation, skin aging [4], and skin cancer [5]. For cosmetics application, the antioxidant agents could be formulated as cream, gel, or lotion [6]. Here, gel preparation, compared to other forms, is more acceptable as gel 0/W system is transparent, washable, greaseless, non-staining, and pleasant appearance [7]. Gel formulation could be formed as nanoemulsion. Advantageously, nanoemulsion is thermodynamically stable, transparent in dispersions [8-10], good in solubilization compared to the solutions, and longer shelf life $[11,12]$. The size of nanoemulsions is submicron in the range of $10-100 \mathrm{~nm}$. The components of nanoemulsion consist of oil, emulsifying agents, and aqueous phases [13-16]. The types of oils used include castor oil, corn oil, coconut oil, mineral oil, or olive oil. Surfactant as the emulsifying agent could be spans, tweens, bentonite, and veegum. Accordingly, these research objectives were to obtain the optimum formulation of rambutan fruit peel extract (RFPE) and to determine the sunscreen protecting factor and antioxidant activity.

\section{MATERIALS AND METHODS}

Materials

Glassware (Pyrex), analytical balance (Ohaus, $d=0.01 \mathrm{mg}$ ), vacuum rotary evaporator (Heidolph), particle size analyzer (PSA) (Horiba SZ100), Viscosimeter (RionViscotester VT-06E), transmission electron microscopy (TEM) (JEOL 1400), spectrophotometer (UV Mini 1240 Shimadzu). RFPEs, Tween 80, propylene glycol, isopropyl myristate, carbopol 940, tri-ethanolamine, methyl paraben, 1,1-diphenyl-2picrylhydrazyl (DPPH) (Merck), ethanol (Merck), oleic acid (Merck), phosphate buffer $\mathrm{pH} 7$, ammonium thiocyanate $30 \%$, $\mathrm{FeCl}_{2}$, $\mathrm{X}$ sunscreen gel, and Vitamin E (Merck). 


\section{Extraction and purification}

The extraction was conducted by maceration using ethanol $96 \%$ as solvent. Liquid extract was evaporated by vacuum rotary to obtain the concentrated extract. Evaporation was continued in water bath to remove all solvents. Fractionation was performed to bleach the color extract using ethanol and n-hexane. Ethanol fraction obtained evaporated on water bath.

\section{Optimization gel nanoemulsion formulation of RFPE Composition of gel nanoemulsion}

A number of materials were required in the gel formulation of nanoemulsion rambutans fruit peel extract, isopropyl myristate (oil), tween 80 (surfactant), propylene glycol (co-surfactant), and water as a solvent. The preparations of nanoemulsion rambutans fruit peel extract were made using a formula design as seen in Table 1, and the established formula used is seen in Table 2 . The formulations result was clear and transparent after $24 \mathrm{hrs}$.

The first steps in making the gel nanoemulsion of RFPE were by mixing RFPE with propylene glycol assisted at the temperature of $75^{\circ} \mathrm{C}$ by stirring for 3 minutes. It was then continued by adding Tween 80 and homogenized by stirring about 3 minutes at the temperature of $75^{\circ} \mathrm{C}$. Myristic oils was added by drops up to volume while stirring was in progress. Nanoemulsion was formed and then was stored for 1 day to obtain the clear liquid. All steps in this research followed a procedure of Syed and Peh [17] with modification. The second steps were by melting the carbopol 940 in warm mortar, adding liquid of methylparaben, and stirring it manually until being homogenous. It was continued by adding triethanolamine and nanoemulsion liquid (first steps) stirred well until the gel was formed.

\section{Evaluation of preparations}

Characterization of nanoemulsion

PSA was used to set a particle size distribution in the preparation of nanoemulsion. Composition formulas for determining particle size included formula 1, 2, 3, and 4. The angle of laser incidence was at $90^{\circ}$, calculated with the median and standard deviation of the replicate for 3 times [18].

Organoleptic test

Organoleptic test was manually performed including the observation of colors, smells, and shapes. The test was performed 3 times replicating every 10 days for 40 days.

Viscosity measurement

The samples of gel were inserted into the pot to be tested. The rotor was placed in the midst of the pot already containing gel sample

Table 1: Formulation design of nanoemulsion of RFPE

\begin{tabular}{lllll}
\hline \multirow{2}{*}{ Content } & \multicolumn{3}{l}{ Formulation } & \\
\cline { 2 - 5 } & F1 & F2 & F3 & F4 \\
\hline RFPE (mg) & 255 & 380 & 510 & 635 \\
Propylene glycol (mL) & 22.5 & 22.5 & 22.5 & 22.5 \\
Tween 80 (mL) & 22.5 & 22.5 & 22.5 & 22.5 \\
Isopropyl myristate (mL) & 5 & 5 & 5 & 5 \\
Aquadest (mL) & 46 & 46 & 46 & 46 \\
\hline
\end{tabular}

RFPE: Rambutan fruit peel extracts

Table 2: Formula of gel nanoemulsion RFPE

\begin{tabular}{lllll}
\hline Content & F1 & F2 & F3 & F4 \\
\hline Carbopol 940 (g) & 0.5 & 0.5 & 0.5 & 0.5 \\
Triethanolamine (g) & 0.6 & 0.6 & 0.6 & 0.6 \\
Ethanol 96\% (mL) & 10 & 10 & 10 & 10 \\
Methylparaben (g) & 0.2 & 0.2 & 0.2 & 0.2 \\
Nanoemulsion (mL) & 88.7 & 88.7 & 88.7 & 88.7 \\
\hline
\end{tabular}

RFPE: Rambutan fruit peel extracts nanoemulsion, and then instrument was turned to make the rotor rotates. The numbers obtained appeared on the screen. Once it stabilized, it was then read on a scale that existed at the viscometer [19].

Dispersive power test

Gel formulation $0.25 \mathrm{~g}$ was carefully weighed and placed in the middle of the glass that has been given a millimeter block. Glass to seal weighed was then placed on the gel and allowed to stand for 1 minute. The diameter of the spread of gel measured at several positions, repeated with the addition of a load of $50 \mathrm{~g} / 1$ minute. Observations were carried out 3 times for each formula gel [19].

\section{Adhesion test}

About $0.50 \mathrm{~g}$ of gel was weighed carefully and placed on two glass objects, and given a load of $1 \mathrm{~kg}$ at the top of the gel flanked by two glass objects for 5 minutes. After being given a load, object glass was attached to the adhesion test equipment that has been prepared. The test began at the moment given the load of $80 \mathrm{~g}$ at each end of the glass object. The time required to start loading was both glass object apart, long was recorded as adhesion gel. Observations were carried out 3 times for each formula gel [19].

\section{Ratio separation test}

Gel was put into a test tube scale-up to a certain scale. Scale tube containing preparations was stored at room temperature. The volume separation of preparation was recorded 10 days once in span of time 40 days. Some tests were conducted at a ratio of 40-day test in parallel using the freeze and thaw method to prevent if there would a failure in the 40-day test to shorten the time. Test method of freeze and thaw was done by storing the preparation for $48 \mathrm{hrs}$ under the conditions of stress with the temperature of $40^{\circ} \mathrm{C}$ and $4^{\circ} \mathrm{C}$ alternately for 6 cycles $(1$ cycle $=24 \mathrm{hrs}$ at a temperature of $40^{\circ} \mathrm{C}$ and $24 \mathrm{hrs}$ at a temperature of $4^{\circ} \mathrm{C}$ ] [20] to observe the physical changes and changes in diameter of the globules by the way of preparation applied in object glass and closed deglass, and then observed globules were formed using a microscope with a magnification of 100 times, and the calculated diameter of the globules average calculated using the formula Edmunson and microscope images photographed with the tools connected to computer device [21]. Edmunson formulas:

Average diameter $=\left[\frac{\sum \text { nd }^{\mathrm{p}+\mathrm{f}}}{\sum \mathrm{nd}^{\mathrm{f}}}\right]^{1 / \mathrm{p}}$

$\mathrm{n}$ : Number of particles in the size range,

$\mathrm{d}$ : One from the halfway line equivalents,

p: Arithmetic index $=1$,

f: Frequency index.

TEM test

Testing nanoemulsion size was dispersed in the base gel preparation using a TEM with $20 \mathrm{~mL}$ sample dripped on TEM carbon-coated copper grid. Grid dried at room temperature [22].

\section{Activity test of sunscreen}

Nanoemulsion gel formulation of RFPE was weighed as much as $0.1 \mathrm{~g}$ and was added and mixed with $10 \mathrm{~mL}$ of $96 \%$ ethanol until becoming homogeneous. Before the use of UV-visible (UV-Vis), spectrophotometer was calibrated beforehand using a $1 \mathrm{~mL}$ form which contains $96 \%$ ethanol, after which the cuvette is inserted. Then, the absorption curve in the test cuvette was made with a wavelength between 290 and $320 \mathrm{~nm}$, ethanol used for blank. After getting the absorbance value, the average absorption (Ar) was determined at the intervals of $5 \mathrm{~nm}$. The results of each absorbance of various concentrations were recorded, and then sun-protecting factor (SPF) calculated the value. SPF value calculation formulas test in vitro:

SPF spectrophotometric $=\mathrm{CF} \times \sum_{290}^{320} \operatorname{EE}(\lambda) \times \mathrm{I}(\lambda) \times \operatorname{Abs}(\lambda)$

EE (1): The spectrum of effects erythema,

I (1): The intensity of the light spectrum, 
Abs: Absorption sunscreen

CF: Correction factor $(=10)$.

The value of $\mathrm{EE} \times \mathrm{I}$ is constant. The value of the wavelength was in the range of 290-320 $\mathrm{nm}$ with $5 \mathrm{~nm}$ in each of difference. The determination was conducted by Sayre et al. [23] as shown in Table 3 .

\section{Antioxidant activity}

Antioxidant activity test of DPPH methods

The gel nanoemulsion samples of RFPEs approximately $1 \mathrm{~g}$ above the porcelain dish are weighed and dissolved in $10 \mathrm{~mL}$ ethanol (extract concentration $255 \mathrm{ppm})$. Afterward, a series of concentrations (5, 7.5, $10,12.5$, and $15 \mu \mathrm{g} / \mathrm{mL}$ ) were made. Several series of concentrations were then pipetted $2 \mathrm{~mL}$ each into $5 \mathrm{~mL}$ flask. In the flask, each was added with $2 \mathrm{~mL}$ of DPPH solution $(0.2 \mathrm{mM})$ and then added with p.a ethanol up to the mark. This was left for 30 minutes at room temperature $\left(25^{\circ} \mathrm{C}\right)$. Subsequently, it was followed by measurement using UV-Vis spectrophotometry at $\lambda$ maximum [24]. The experiments were performed 3 times. The same treatment was also carried out on nanoemulsion gel without extract, gel comparator " $\mathrm{X}^{\circledR}$ Sunscreen Gel," and Vitamin E.

Antioxidant activity test with ferric thiocyanate (FTC) methods The sample of approximately $1 \mathrm{~g}$ of gel nanoemulsion of RFPEs in a porcelain dish was weighed and dissolved in $10 \mathrm{~mL}$ ethanol in the flask. Vitamin E weighed $10 \mathrm{mg}$ on a watch glass was then dissolved with ethanol to $10 \mathrm{~mL}$ in the flask. About $4 \mathrm{~mL}$ of the solution was taken using a measuring pipette, put into a flask, and added with $4.1 \mathrm{~mL}$ of $2.52 \%$ oleic acid, $3.9 \mathrm{~mL}$ of distilled water, and added phosphate buffer $\mathrm{pH}$ 7-25 mL in the flask. This mixture, also called the stock solution, was incubated at a temperature of $40^{\circ} \mathrm{C}$ in the oven. Around $0.1 \mathrm{~mL}$ of stock solution was added to a reading of $0.1 \mathrm{~mL}$ of $30 \%$ ammonium thiocyanate and $0.1 \mathrm{~mL}$ of $0.02 \mathrm{M} \mathrm{FeCl}_{2}$ in a flask and added with ethanol $75 \% \mathrm{v} / \mathrm{v}$ to $10 \mathrm{~mL}(9.7 \mathrm{~mL})$ and incubated at room temperature for 3 minutes. Read at a wavelength of $500 \mathrm{~nm}$ [25]. Measurements were made every $24 \mathrm{hrs}$ until the absorbance of control (a mixture of $2.52 \%$ oleic acid, phosphate buffer $\mathrm{pH} 7$, distilled water, and solvent extracts) reached a maximum. The same treatment was also carried out on the nanoemulsion gel without extract, gel comparator " $\mathrm{X}^{\circledR}$ Sunscreen Gel," and Vitamin E.

\section{RESULTS AND DISCUSSION}

\section{Size characterization of gel nanoemulsion of RFPE}

PSA showed that the distributions of particle size of the formula 1-4 (Fig. 1) were $13.3 \pm 4.0,9.7 \pm 1.9,13.6 \pm 2.7$, and $14.5 \pm 2.5 \mathrm{~nm}$, respectively. The particle formed was quite small for the co-surfactant penetrate of the wall of film surfactant which later reduced fluidity and viscosity of nanoemulsion [26].

Based on the observation of gel nanoemulsion, RFPE with 100 times magnification did not showed any forms of globule and particle size at range nano size. That was the sign of stability of gel nanoemulsion RFPE although the gel exposed at extreme temperature. The following study is to observe the morphology of gel nanoemulsion of RFPE by TEM (Fig. 2).

The result of TEM determination was in line with previous assay in which the morphology of gel nanoemulsion of F1 formed the aggregate of nanoparticle that still dispersed well on the gel. This result fit to the findings of Ben et al. [27].

\section{Physical characterization of gel nanoemulsion of RFPE}

Based on the physical characterization of RFPE, the characteristics such as spreadability, viscosity, pH, and adhesiveness (Table 4) met the standard.

Due to statistical analysis, ANOVA, the concentration of extract interfered the physical properties of nanoemulsion. Based on stability
Table 3: Determination spectrum of effects erytherma

\begin{tabular}{ll}
\hline Wavelength $(\boldsymbol{\lambda} \mathbf{n m})$ & EExI (normalized) \\
\hline 290 & 0.0150 \\
295 & 0.0817 \\
300 & 0.2874 \\
305 & 0.3278 \\
310 & 0.1864 \\
315 & 0.0839 \\
320 & 0.0180 \\
Total & 1.0000 \\
\hline
\end{tabular}

EE: Erythemal effect spectrum, I: Solar intensity spectrum

Table 4: Physical characteristics of RFPE $(n=3)$

\begin{tabular}{lllll}
\hline Formula & \multicolumn{4}{l}{ Average \pm SD } \\
\cline { 2 - 5 } & pH & Viscosity & Adhesiveness & Spreadability \\
\hline F1 & $6 \pm 0$ & $126.66 \pm 5.77^{*}$ & $2.41 \pm 0.21^{*}$ & $10.46 \pm 0.28^{*}$ \\
F2 & $6 \pm 0$ & $93.33 \pm 11.54^{*}$ & $2.65 \pm 0.20^{*}$ & $11.54 \pm 0.34^{*}$ \\
F3 & $6 \pm 0$ & $96.66 \pm 5.77^{*}$ & $2.00 \pm 0.13^{*}$ & $11.44 \pm 0.34^{*}$ \\
F4 & $6 \pm 0$ & $66.66 \pm 5.77^{*}$ & $1.59 \pm 0.14^{*}$ & $11.95 \pm 0.30^{*}$ \\
\hline
\end{tabular}

*Significance. SD: Standard deviation, RFPE: Rambutan fruit peel extracts
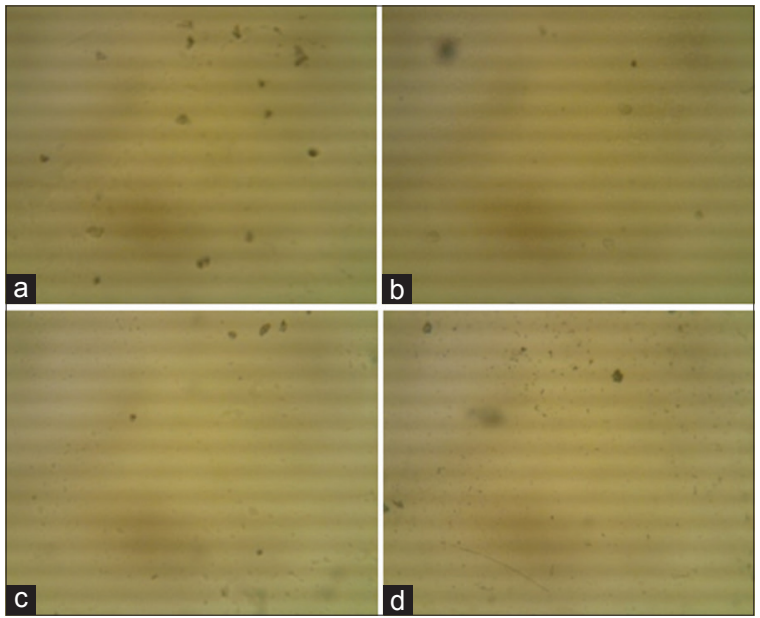

Fig. 1: Microscopic appearance of gel nanoemulsion rambutan fruit peel extract at the last cycle on freeze thaw method, (a) Formula 1, (b) formula 2, (c) formula 3, and (d) formula 4

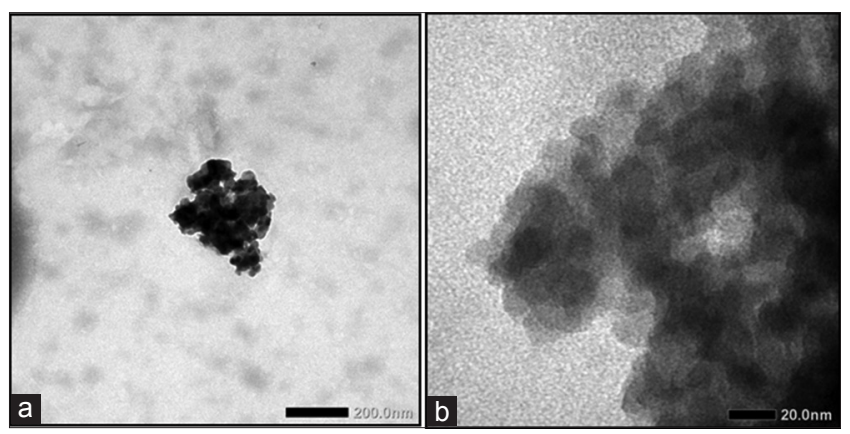

Fig. 2: Particles of nanoemulsion of rambutan fruit peel extracts (a) transmission electron microscopy (TEM) scale $200 \mathrm{~nm}$ and (b) TEM scale $20 \mathrm{~nm}$

test accelerated using freeze thaw in low $\left(4 \pm 2^{\circ} \mathrm{C}\right)$ and high temperature $\left(40 \pm 2^{\circ} \mathrm{C}\right)$, all formulations indicated good stability, such as homogeneity, organoleptic, $\mathrm{pH}$, and viscosity.

Further study determines the ability of SPF. The result showed that SPF of nanoemulsion in formulation (F4) had a better value compared to other formulations (Table 5). 
The result was in line with the previous research of Ebrahimzadeh et al. [28], which stated that the fruit peel extract of rambutan had a sun protection factor. Based on Wasitaatmaja [29] classification of SPF, the nanoemulsion of fruit peel extract had a high SPF due to value SPF at the range of 8-15. In contrast, formulation F3 had the good characteristics due to viscosity value at $96.66 \pm 5.77 \mathrm{dPas}$; as a consequent, it was easy to apply and distribute homogenous in the skin. In addition, the spreading ability and adhesiveness were good.

\section{Determination antioxidant activity by DPPH method}

Determination antioxidant activity based on radical scavenging was performed toward the formulas and commercial product and vitamin $\mathrm{E}$. The result of inhibitory concentration $50 \%\left(\mathrm{IC}_{50}\right)$ of the samples showed that the highest value was found in the nanoemulsion of fruit peel extract with the value of $9.32 \mu \mathrm{g} / \mathrm{mL}$. Meanwhile, the $\mathrm{IC}_{50}$ of commercial product and Vitamin $\mathrm{E}$ values were at 40.41 and $10.41 \mu \mathrm{g} / \mathrm{mL}$, respectively [30]. Classifying the antioxidant activity was based on the $\mathrm{IC}_{50}$ value into four types: Very active $(<50 \mu \mathrm{g} / \mathrm{mL})$, active $(50-100 \mu \mathrm{g} / \mathrm{mL})$, weak $(100-200 \mu \mathrm{g} / \mathrm{mL})$, and inactive $(>200 \mu \mathrm{g} / \mathrm{mL})$. Consequently, the antioxidant activities of the samples were very active. These results have been supported by the antioxidant activity index (AAI) value obtained from three samples. AAI value or AAI is a value that categorizes antioxidant activity to be weak, medium, strong, and very strong based on the obtained value of AAI. AAI value was obtained by using the formula where DPPH concentration $(\mu \mathrm{g} / \mathrm{mL})$ used divided by the $(\mu \mathrm{g} / \mathrm{mL})$ $\mathrm{IC}_{50}$ were obtained. AAI values obtained for gel nanoemulsion RFPE was 8.58 (very strong), gel nanoemulsion without extract was 0.08 (inactive), commercial product was 1.98 (strong), and Vitamin E was 7.68 (very strong).

The gel nanoemulsion of RFPEs had high antioxidant activity for containing the phenolic and flavonoid compounds such as ellagic acids, corilagin, and geraniin responsible for antioxidant activity [3]. The class of phenolic and flavonoid compounds had a hydroxyl group $(\mathrm{OH})$ attached to the aromatic ring later donating a hydrogen atom $(\mathrm{H})$ into free radicals, which later became stable. Vitamin E also had a high antioxidant activity for having a hydroxyl group $(\mathrm{OH})$ attached to an aromatic ring.

In the study conducted by Muhtadi et al. [2], it has been shown that RFPEs had a radical inhibitory activity value $\left(\mathrm{IC}_{50}\right)$ of $7.74 \pm 0.76 \mu \mathrm{g} /$ $\mathrm{mL}$. In this study, RFPE has been formulated in a gel nanoemulsion and radical values obtained inhibitory activity $\left(\mathrm{IC}_{50}\right)$ of $9.32 \pm 0.05 \mu \mathrm{g} / \mathrm{mL}$. This data showed that the gel formulation nanoemulsion has a strong antioxidant activity as well as the extract of the fruit peel of rambutan. The blank formulation showed no antioxidant activity in which IC $_{50}$ value was $968.24 \pm 420.740 \mu \mathrm{g} / \mathrm{mL}$. The difference between antioxidant activity of RFPE and commercial product and Vitamin E were not statistically significant, meaning that the activity was equal. However, the $\mathrm{IC}_{50}$ value of nanoemulsion was smaller than other samples (Table 6).

\section{Determination of antioxidant activity by FTC method}

FTC method was based on the inhibition of lipid peroxidation reaction. It was done by measuring the amount of peroxide in the process of lipid peroxidation and ferri thiocyanate complexes formed was read at a wavelength $(\lambda)$ of $500 \mathrm{~nm}$. Unsaturated fats lose hydrogen atoms $(\mathrm{H})$ in $\mathrm{CH}_{2}$ group, resulting in carbon atoms unpaired $(\mathrm{CH})$. Afterward, the chain reaction and antioxidant compounds in the sample broke the chain reaction in a manner donor hydrogen atom $(\mathrm{H})$ [31]. A low absorbance showed high antioxidant activity of free radicals formed during lipid peroxidation. The reading of lipid peroxidation process was carried out to obtain the maximum absorbance value of control. Radical inhibition profile is tested for 6 days with a range of sample readings every 24 hrs.

The sample had the antioxidant activity if the absorbance of sample was lower than control. The high absorbance of control was in view of the
Table 5: SPF value

\begin{tabular}{ll}
\hline Formulation & SPF \\
\hline F1 & $6.45 \pm 0.002$ \\
F2 & $9.37 \pm 0.002$ \\
F3 & $10.12 \pm 0.001$ \\
F4 & $13.12 \pm ., 001$ \\
Control (-) & $3.05 \pm 0.001$ \\
Vitamin E & $30.25 \pm 0.002$ \\
\hline
\end{tabular}

SPF: Sun protection factor

Table 6: $\mathrm{IC}_{50}$ and AAI $(\mathrm{n}=3)$

\begin{tabular}{lll}
\hline Sample & IC $_{\mathbf{5 0}}(\boldsymbol{\mu g} / \mathbf{m L})$ & AAI \\
\hline Gel nanoemulsion of RFPE & $9.32 \pm 0.05$ & 8.58 \\
Gel nanoemulsion without extract & $968.24 \pm 420.740$ & 0.08 \\
Commercial product & $40.41 \pm 0.98$ & 1.98 \\
Vitamin E & $10.41 \pm 0.05$ & 7.68 \\
\hline
\end{tabular}

AAI: Antioxidant activity index, $\mathrm{IC}_{50}$ : Inhibitory concentration $50 \%$,

RFPE: Rambutan fruit peel extracts

Table 7: \% Inhibition of samples on the $4^{\text {th }}$ day $(n=3)$

\begin{tabular}{ll}
\hline Sample & \% Inhibition \\
\hline Gel nanoemulsion RFPE & $51.09 \pm 0.99$ \\
Gel nanoemulsion without extract & 0 \\
Commercial product & $60.07 \pm 13.23$ \\
Vitamin E & $79.07 \pm 7.62$ \\
\hline RFPE: Rambutan fruit peel extracts &
\end{tabular}

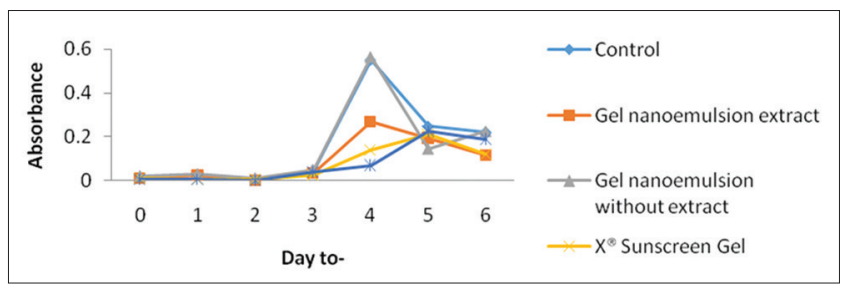

Fig. 3: Absorbance profile of control, gel nanoemulsion rambutan fruit peel extract, gel nanoemulsion without extract, commercial product, and Vitamin E

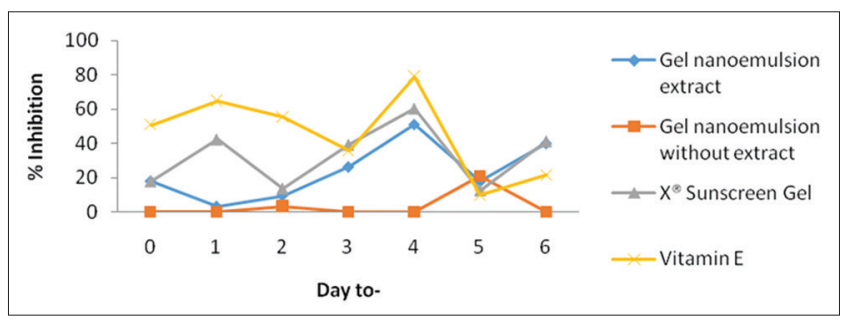

Fig. 4: Inhibition ferric thiocyanate profile of gel nanoemulsion of rambutan fruit peel extract, gel nanoemulsion without any extract, commercial product, and Vitamin E

absence of antioxidant agent. As a result, the concentration of ion ferri formed was high so that the red color formed more intense from the complex of ferri and ammonium thiocyanate. In spite of the presence of samples, the concentration of ion ferri was lower. The absorbance of samples (nanoemulsion gel, Vitamin E, and commercial product) had an antioxidant activity. There are some similarities between the absorbance profile of nanoemulsion gel of RFPEs and commercial product. In contrast, gel nanoemulsion without extract obtained absorbance values greater than control. 
Table 7 shows the percentage inhibition FTC on all samples tested on the $4^{\text {th }}$ day at which the absorbance values were obtained for maximum control. Vitamin E had the highest inhibition, followed by commercial product and nanoemulsion of RFPE with the percentage value of $79.07 \pm 7.62 \%$; $60.07 \pm 13.23 \%$, and $51.09 \pm 0.99 \%$, consecutively. There was no significant difference between gel nanoemulsion of RFPEs and commercial product based on the significant value equal to 1.000 $(\mathrm{p}>0.05)$.

Based on the results of antioxidant activity, both DPPH and FTC method of nanoemulsion RFPE were eligible to be used as an antioxidant in cosmetic preparations. Their differences and measurement of antioxidant mechanisms between the two methods have led to a number of differences in the results of antioxidant activity [32]. The content of phenolic and flavonoid compounds in the gel nanoemulsion of RFPE was responsible for antioxidant activity using DPPH and FTC method. In addition, ellagic acid, corilagin, and geraniin are the examples of active chemical compound of RFPE.

\section{CONCLUSIONS}

1. The gel nanoemulsion of RFPEs of FIII had a good physical stability

2. The gel nanoemulsion of RFPEs had a sunscreen activity

3. The antioxidant activity of gel nanoemulsion of RFPE by DPPH and FTC methods was at IC ${ }_{50}$ value of $9.32 \pm 0.05 \mu \mathrm{g} / \mathrm{mL}$ and $\%$ inhibition of $51.09 \pm 0.99 \%$.

\section{REFERENCES}

1. Muhtadi M, Haryoto H, Sujono TA, Suhendi A. Antidiabetic and antihypercholesterolemia activities of Rambutan (Nephelium lappaceum L.) And durian (Durio zibethinus Murr.) Fruit peel extracts. J Appl Pharm Sci 2016;6(4):190-4.

2. Muhtadi M, Sujono TA, Indrayudha P, Suhendi A, Yen KH. Antioxidant activity and chemical constituents of some Indonesian fruit peels. Med Plants 2014;6(1):1-4.

3. Thitilertdecha N, Teerawutgulrag A, Kilburn JD, Rakariyatham N. Identification of major phenolic compounds from Nephelium lappaceum L. And their antioxidant activities. Molecules 2010;15(3):1453-65.

4. Wang SQ, Stanfield JW, Osterwalder U. In vitro assessments of UVA protection by popular sunscreens available in the United States. J Am Acad Dermatol 2008;59(6):934-42.

5. Paye M, Barel AO, Maibach HI. Handbook of Cosmetic Science and Technology. $3^{\text {rd }}$ ed. New York: Informa Healthcare; 2009.

6. Winarsi H. Antioksidan Alami dan Radikal Bebas. Yogyakarta: Penerbit Kanisius; 2007.

7. Jain A, Gautam SP, Gupta Y, Khambete H, Jain S. Development and characterization of ketoconazole emulgel for topical drug delivery. Pharm Sin 2010;1(3):221-31.

8. Baboota S, Shakeel F, Ahuja A, Ali J, Shafiq S. Design development and evaluation of novel nanoemulsions formulations for transdermal potential of celecoxib. Acta Pharm 2007;57(3):315-32.

9. Shafiq S, Shakeel F, Talegaonkar S, Ahmad FJ, Khar RK, Ali M. Development and bioavailability assessment of ramipril nanoemulsion formulation. Eur J Pharm Biopharm 2007;66(2):227-43.

10. Shakeel F, Baboota S, Ahuja A, Ali J, Aqil M, Shafiq S. Nanoemulsions as vehicles for transdermal delivery of aceclofenac. AAPS PharmSciTech 2007;8(4):E104

11. Shafiq S, Shakeel F, Talegaonkar S, Ahmad FJ, Khar RK, Ali M. Design and development of oral oil in water ramipril nanoemulsion formulation: In vitro and in vivo assessment. J Biomed Nanotechnol 2007;3(1):28-44.
12. Aparna C, Srinivas P, Patnaik KS. Enhanced transdermal permeability of telmisartan by a novel nanoemulsion gel. Int J Pharm Pharm Sci 2015;7(4):335-42.

13. Gasco MR, Gallarate M, Pattarino F. In vitro permeation of azelaic acid from viscosized microemulsions. Int J Pharm 1991;69(3):193-6.

14. Kriwet K, Müller-Goymann C. Diclofenac release from phospholipid drug systems and permeation through excised human stratum corneum. Int J Pharm 1995;125:231-42.

15. Trotta M. Influence of phase transformation on indomethacin release from microemulsions. J Control Release 1999;60(2-3):399-405.

16. Drais HK, Hussein AA. Formulation and characterization of carvedilol nanoemulsion oral liquid dosage form. Int $\mathrm{J}$ Pharm Pharm Sci 2015;7(12):209-16.

17. Syed HK, Peh KK. Identification of phases of various oil, surfactant/cosurfactants and water system by ternary phase diagram. Acta Pol Pharm 2014;71(2):301-9.

18. Oliveira JS, Aguiar TA, Mezadri H, Dos Santos OD. Attainment of hydrogel-thickened nanoemulsions with tea tree oil (Melaleuca alternifolia) and retinylpalmitate. Afr J Biotechnol 2011;10(60):13014-8.

19. Marchaban, Sulaiman TN. Petunjuk Praktikum Formulasi dan Teknologi Sediaan Cair dan Semi Padat. Yogyakarta: Faculty of Pharmacy, UGM; 2014.

20. Agustin R, Oktadefitri Y, Lucida H. Formulasi Krim Tabir Surya dari Kombinasi Etil p-Metoksinamat dengan Katekin. Proceeding of National Seminar on Latest Development of Pharmaceutical and Clinical Science III; 2013. p. 184-98.

21. Dewi R, Anwar E, Yunita KS. Uji stabilitas fisik formula krim yang mengandung ekstrak kacang kedelai (Glycine max). Pharm Sci Res 2014;1(3):194-208.

22. Savaliya C, Rathod KN, Dhruv D, Markna JH. Preparation of nanostructured copper oxide rods using advanced sonication method. Int J Nanosci Nanoeng 2015;2(4):27-31.

23. Sayre RM, Agin PP, LeVee GJ, Marlowe E. A comparison of in vivo and in vitro testing of sunscreening formulas. Photochem Photobiol 1979;29:559-66.

24. Molyneux P. The use of the stable free radical diphenylpicrylhydrazyl (DPPH) for estimating antioxidant activity. J Sci Technol 2004;26(2):211-9.

25. Rezaeizadeh A, Zuki AB, Abdollahi M, Goh YM, Noordin MM, Hamid $\mathrm{M}$, et al. Determination of antioxidant activity in methanolic and chloroformic extracts of Momordica charantia. Afr J Biotechnol 2011;10(24):4932-40.

26. Tenjarla S. Microemulsions: An overview and pharmaceutical applications. Crit Rev Ther Drug Carrier Syst 1999;16(5):461-521.

27. Ben ES, Suardi M, Chalid TC, Yulianto T. Optimasi Nanoemulsi Minyak Kelapa Sawit (palm oil) Menggunakan Sukrosa Monoester. Prosiding Seminar Nasional Perkembangan Terkini Sains Farmasi dan Klinik III; 2013. p. 31-62.

28. Ebrahimzadeh MA, Enayatifard R, Khalili M, Ghaffarloo M, Saeedi M, Yazdani Charati J. Correlation between sun protection factor and antioxidant activity, phenol and flavonoid contents of some medicinal plants. Iran J Pharm Res 2014;13(3):1041-7.

29. Wasitaatmaja SM. The Guidance for Medical Cosmetic Sciences [Penuntun Ilmu Kosmetik Medik]. Jakarta: UI Press; 1997.

30. Reynertson K. Phytochemical Analysis of Bioactive Constituents from Edible Myrtaceae Fruits. Dissertation Submitted to the Graduate Faculty in Biology in Partial Fulfillment of the Requirements for the Degree of Doctor of Philosophy. The City University of New York; 2007.

31. Devasagayam TP, Tilak JC, Boloor KK, Sane KS, Ghaskadbi SS, Lele RD. Free radicals and antioxidants in human health: Current status and future prospects. J Assoc Physicians India 2004;52:794-804.

32. Zahin M, Aqil F, Ahmad I. The in vitro antioxidant activity and total phenolic content of four Indian medicinal plants. Int J Pharm Pharm Sci 2009; 1 Suppl 1:88-95. 